Dzieje Najnowsze, Rocznik LIII - 2021, 2

PL ISSN 0419-8824

\author{
Małgorzata Dajnowicz \\ https://orcid.org/0000-0001-6124-9983 \\ Uniwersytet w Białymstoku
}

\title{
Liga Kobiet Polskich w okręgu łódzkim w latach 1982-1989. Główne kierunki działalności w świetle materiałów sprawozdawczych organizacji*
}

\begin{abstract}
Abstrakt: Liga Kobiet Polskich, akceptowana przez władze komunistyczne organizacja kobieca, usiłowała umocnić swoje wpływy zwłaszcza wśród kobiet pracujących. Jako priorytetowy cel działalności wskazywała także upowszechnianie znaczenia szerokich działań Komitetu Gospodarstwa Domowego, w ramach którego organizowano szkolenia zawodowe, promowano gospodarność w prowadzeniu przez kobiety gospodarstw domowych. Schyłek jej działalności przypadł na koniec lat osiemdziesiątych, biorąc pod uwagę zarówno zmniejszającą się liczbę członkiń, jak i słabnącą pozycję jako oficjalnej reprezentacji kobiet polskich.
\end{abstract}

Słow a kluczowe: Liga Kobiet Polskich, praca zawodowa kobiet, ruch kobiecy w PRL, Komitet Gospodarstwa Domowego.

Abstract: The Polish Women's League, a women's organisation accepted by the communist authorities, tried to strengthen its influence, especially among working women. Its other priority was popularising the Household Committee activities, which organised vocational education and promoted household economics. Unfortunately, it was declining in the late 1980s because of decreasing number of female members and its waning position as the official representation of Polish women.

Key w or d s: Polish Women's League, women's professional work, women's movement of Polish People's Republic, Household Committee.

* Artykuł przygotowany w ramach realizacji projektu badawczego Narodowego Centrum Nauki pt. „Liga Kobiet w terenie. Działalność organizacji i realia jej funkcjonowania na szczeblu regionalnym i lokalnym w rzeczywistości Polski Ludowej (1945-1989)", nr 2017/25/B/ HS3/02015. 
Dotychczas nie prowadzono szczegółowych badań nad znaczeniem i rola ruchu kobiecego w poszczególnych regionach kraju, funkcjonującego pod nazwą Liga Kobiet (LK). Jak dotąd nie powstała żadna zwarta monografia naukowa omawiająca działalność LK w latach 1945-1989. Aktualne ustalenia badawcze, odnoszące się do funkcjonowania kobiet polskich w rzeczywistości po 1945 r., dotyczyły głównie wykazania niesamodzielności ruchu kobiecego i jego zależności od ówczesnej polityki władz komunistycznych. Opublikowane artykuły na ten temat traktować należy jako wstęp do szerszych, kompleksowych badań naukowych. Barbara Nowak w pracy doktorskiej podała ważne ustalenia w zakresie działalności LK na tle rzeczywistości PRL. Praca ta wymaga jednak uzupełnień z powodu niewykorzystania dostępnych materiałów źródłowych, zgromadzonych m.in. w polskich archiwach państwowych ${ }^{1}$. Istotne ustalenia badawcze o ruchu kobiecym w Polsce po 1945 r. poczyniła Magdalena Grabowska². Do działalności organizacji nawiązywali: w monografiach Małgorzata Fidelis ${ }^{3}$ i Natalia Jarska ${ }^{4}$, a w artykułach naukowych - Dariusz Jarosz $^{5}$ i Anna Marcinkiewicz-Kaczmarczyk ${ }^{6}$. Ostatnio opublikowano kilka tekstów naukowych, które stanowić moga przyczynek do kompleksowego opracowania zasięgu działalności LK w tzw. terenie, na poziomie regionalnym i lokalnym. W obiegu naukowym znalazły się również artykuły o funkcjonowaniu LK w takich regionach, jak województwa białostockie ${ }^{7}$ i łódzkie ${ }^{8}$ czy Dolny Ślask ${ }^{9}$. Opracowania te dotyczą jednak działalności LK w rzeczywistości

${ }^{1}$ B. Nowak, Serving Women and the State. The League of Women in Communist Poland, PhD diss. The Ohio State University, 2004, http://bit.ly/2diMB3h (dostęp: 5 V 2020).

${ }^{2}$ M. Grabowska, Zerwana genealogia. Działalność społeczna i polityczna kobiet po 1945 roku a wspótczesny polski ruch kobiecy, Warszawa 2018.

${ }^{3}$ M. Fidelis, Kobiety, komunizm i industrializacja $w$ powojennej Polsce, Warszawa 2015.

${ }^{4}$ N. Jarska, Kobiety $z$ marmuru. Robotnice $w$ Polsce $w$ latach 1945-1960, Warszawa 2015.

${ }_{5}^{5}$ D. Jarosz, Idee, programy i realia: funkcje Ligi Kobiet $w$ porzadku instytucjonalnym Polski Ludowej (1945-1957), w: Działaczki społeczne, feministki, obywatelki... Samoorganizowanie się kobiet na ziemiach polskich po 1918 roku (na tle porównawczym), t. II, red. A. Janiak-Jasińska, K. Sierakowska, A. Szwarc, Warszawa 2009, s. 307-330.

${ }^{6}$ A. Marcinkiewicz-Kaczmarczyk, Rola kobiety $w$ Polsce Ludowej w świetle treści propagandowych rozpowszechnianych przez Lige Kobiet w latach 1946-1956, „Dzieje Najnowsze” 2018, nr 2, s. 149-179.

${ }^{7}$ M. Dajnowicz, Główne kierunki działalności Ligi Kobiet w Polsce Ludowej do 1975 roku (ze szczególnym uwzględnieniem województwa białostockiego), „Prace Historyczne” 2018, $\mathrm{nr} 145$ (3), s. 579-601; eadem, Liga Kobiet $w$ terenie. Kierunki dziatalności organizacji na przykładzie struktur białostockich w latach 1966-1981, „Niepodległość i Pamięć” 2018, t. XXV, nr 2, s. 161-182; A. Drozdowska, Liga Kobiet w województwie białostockim - stan badań i postulaty badawcze, „Czasopismo Naukowe Instytutu Studiów Kobiecych” 2018, nr 2 (5), s. 112-127.

${ }^{8}$ M. Dajnowicz, Liga Kobiet w okręu tódzkim w latach 1945-1981. Gtówne obszary działalności, „Dzieje Najnowsze” 2019, nr 4, s. 75-90.

9 A. Miodowski, Local conditions for the activities of the League of Women structures in the Lower Silesia during the Stalinist period, „Społeczeństwo i Polityka” 2018, nr 4 (57), 
Polski lat 1945-1981. Okres funkcjonowania organizacji pod nazwa Liga Kobiet Polskich (LKP), czyli od 1982 r., w bardzo ograniczonym stopniu poddawany był analizie naukowej z powodu m.in. braku dostępnych źródeł archiwalnych ${ }^{10}$. Ponadto nie opublikowano jak dotąd żadnych tekstów naukowych traktujących o działalności LKP na obszarze łódzkim. Niniejszy artykuł jest próbą omówienia głównych kierunków działalności organizacji w latach 1982-1989 w okręgu łódzkim. W tekście wykorzystano głównie, oprócz prasy związanej z Liga, tj. „Zwierciadła” oraz „Naszej Pracy”, nieznane materiały wewnętrzne przechowywane w Archiwum LKP w Łodzi - przede wszystkim sprawozdania i raporty z działalności organizacji (zarządu wojewódzkiego, częściowo również kół dzielnicowych). Analiza tych materiałów pozwoliła na zaprezentowanie kierunków działalności łódzkiej LKP w latach osiemdziesiątych, odzwierciedlonych w materiałach sprawozdawczych. Przyjęto w opracowaniu założenie, że organizacja, mimo podjętych prób „odnowy” organizacyjnej i wprowadzonych zmian programowych, zapowiadanych przy tworzeniu nazwy LKP oraz dalej realizacji pewnych działań, zwłaszcza w środowiskach kobiet pracujacych czy w różnorodnych inicjatywach Komitetu Gospodarstwa Domowego, kierowanych do różnych środowisk kobiecych, nie była w stanie „odzyskać" utraconej pozycji, ugruntowanej we wcześniejszym okresie ${ }^{11}$. Na lata osiemdziesiate przypadł bowiem schyłek jej zasięgu oddziaływania w środowiskach kobiet łódzkich, powodowany m.in. postępującym po $1981 \mathrm{r}$. kryzysem polityczno-gospodarczym i związana z tym utrata zaufania kobiet niezrzeszonych w Lidze do organizacji, która utożsamiana była w ogólnym odbiorze społecznym z upadającym w tym czasie systemem komunistycznym.

Nazwę LKP ustalono podczas Nadzwyczajnego Zjazdu (NZ) LK pod koniec listopada 1981 r. w Warszawie. Termin zjazdu nie był przypadkowy, bowiem jego obrady zbiegły się w czasie z VI Plenum Komitetu Centralnego Polskiej Zjednoczonej Partii Robotniczej (KC PZPR), podczas którego dyskutowano m.in. na temat postępującego po 1981 r. kryzysu politycznego w Polsce i jego skutków. Na początku zjazdu LK nawiązywano także do podejmowanej podczas plenum tematyki, podkreślając, że obrady Ligi, jak i plenum odbywać się miały

s. 137-155; idem, Udziat dolnoślaskiej Ligi Kobiet w kampaniach propagandowych na rzecz aktywizacji zawodowej kobiet ze środowisk patologicznych $i$ aspołecznych (1949-1955), „Niepodległość i Pamięć” 2019, t. XXVI, nr 1, s. 279-302.

${ }^{10} \mathrm{Z}$ poczynionych przez mnie ustaleń wynika, że materiały archiwalne $\mathrm{z}$ lat osiemdziesiatych, które gromadzono w placówkach wojewódzkich LK, w wielu przypadkach nie były przekazywane przez organizację do archiwów państwowych. Dotarłam do Archiwum Ligi Kobiet Polskich w Łodzi. Materiały zawierają informacje z działalności organizacji z obszaru województwa łódzkiego oraz - choć w mniejszym stopniu - Zarządu Głównego organizacji.

${ }^{11}$ Największe sukcesy łódzka LK notowała w latach sześćdziesiątych i siedemdziesiątych. Pewnego rodzaju kryzys jej aktywności, spowodowanej m.in. pogarszająca się sytuacja polityczno-gospodarczą kraju, zauważalny był już na przełomie lat siedemdziesiątych i osiemdziesiątych. Zob. M. Dajnowicz, Liga Kobiet w okręgu tódzkim..., s. 85-86. 
„w okresie pogłębionego się kryzysu społeczno-politycznego i ekonomicznego, szerzącej się fali strajków i anarchii, dezorganizacji życia a jednocześnie społecznej konsolidacji i porozumienia narodowego"12. Ówczesne władze zwracając się do środowisk reprezentujących kobiety o podjęcie współpracy w zakresie przeciwdziałania szeroko rozumianemu kryzysowi, zdawały sobie sprawę z faktu, że to kobiety moga być ich sojuszniczkami w upowszechnianiu w latach osiemdziesiątych porządku społecznego, gospodarczego i politycznego zgodnego z wytycznymi partyjno-rządowymi. Środowiska kobiece miała reprezentować właśnie $\mathrm{LKP}^{13}$.

W NZ LK udział wzięło łącznie blisko 400 delegatek. Wśród głównych gości zjazdu znalazła się Zofia Grzyb, kierownik Wydziału Społeczno-Zawodowego KC PZPR. Obrady zainaugurowano referatem programowym prezydium ustępującego Zarządu Głównego (ZG) LK. W jego treści znalazły się wątki na temat historii działalności ruchu kobiecego w Polsce Ludowej, głównych obszarów aktywności LK i jej dokonań począwszy od 1945 r. Wśród osiąnięć organizacji wskazywano m.in. na kwestie angażowania się liderek z Ligi w prace opiniodawcze w zakresie powstających wówczas ustaw, dotyczące chociażby prawa rodzinnego (ustawy z 1964 r.) i funduszu alimentacyjnego (zwłaszcza obowiązująca od 1974 r.), co stać miało w sprzeczności z funkcjonująca w części społeczeństwa opinią o Lidze jako „reprezentacji wyłącznie emerytek lub miejskich gospodyń domowych, które winny zajmować się kuchnią, klatka schodową i podwórkiem"14. Dowodzono w dyskusjach zjazdowych, właśnie wbrew niektórym opiniom społecznym, że LK w swej wieloletniej działalności przyczyniała się do rozwiązania wielu ogólnospołecznych problemów, chociażby poprzez funkcjonujacy od 1957 r. KGD, którego wyszkolone pod auspicjami Ligi instruktorki edukowały Polki w zakresie prowadzenia nowoczesnego i oszczędnego gospodarstwa domowego czy stosowania w życiu codziennym zdrowych zasad żywieniowych, upowszechnianych następnie w polskich rodzinach. Podczas zjazdu przyznano się także do słabości Ligi i popełnianych w przeszłości błędów wynikających, jak podawano, z jej niedostatecznego zaangażowania w szeroko rozumiane problemy kobiet. Na postawione $\mathrm{w}$ jednym z wystapień pytanie: „dlaczego brak nam siły przebicia?”, odpowiedziano, że w przeszłości sprawy kobiet również przez władze traktowane były niekiedy instrumentalnie, jako drugorzędne i mało istotne, czemu Liga nie potrafiła zdecydowanie się przeciwstawić. Wśród błędów Ligi, jako organizacji reprezentującej Polki z różnych środowisk, wskazywano także na brak solidarności z kobietami z Wybrzeża podczas strajków sierpniowych w 1980 r. czy protestów i strajków włókniarek łódzkich w 1971 r. Szeroko rozumianych

${ }^{12}$ VIII Nadzwyczajny Zjazd Krajowy Ligi Kobiet, „Nasza Praca” 1981, nr 1, s. 2.

${ }^{13}$ Zob. P. Kenney, Pojęcie „matki-Polki” w języku opozycji i wtadzy, w: Komunizm. Ideologia, system, ludzie, red. T. Szarota, Warszawa 2001, s. 344-351.

${ }^{14}$ A jednak dziatała, „Nasza Praca” 1981, nr 1, s. 11. 
zmian $\mathrm{w}$ dalszym funkcjonowaniu organizacji domagać się miały głównie liderki oddziałów terenowych, zwłaszcza z Wybrzeża, w tym z Gdańska ${ }^{15}$.

Przyznanie się do błędów popełnianych w działaniach w przeszłości miało wzbudzić szersze zaufanie kobiet do LK, zrzeszonych i nienależących do organizacji, uzasadniać zmiany w wytyczaniu po $1981 \mathrm{r}$. dalszych działań Ligi, funkcjonującej już pod nowa, szerszą nazwą. W celach zjazdu akcentowano również potrzebę wypracowania koncepcji prowadzącej do wzmocnienia wśród Polek pozycji i autorytetu LKP, odnowionej w swych strukturach, bardziej masowej i jednocześnie nowocześniejszej niż przed 1982 r., reprezentującej interesy wszystkich kobiet polskich z różnych środowisk społecznych, zawodowych, grup pokoleniowych, na co wskazywała właśnie szersza nazwa ${ }^{16}$. LKP miała być organizacją „nie tylko z osiedla, Liga Kobiet nie tylko emerytek, gospodyń domowych - bo i takie wyobrażenie w Lidze panowało dotychczas w środkach masowego przekazu - lecz ma być to Liga wszystkich Polek, które uznają ja za swoja, Polek pracujących zawodowo i prowadzących gospodarstwa rodzinne, młodych i starszych, robotnic i naukowców, kobiet wszystkich środowisk i zawodów" - pisano w relacji ze zjazdu, opublikowanej na łamach „Naszej Pracy”"17.

Zakładano, że do działań priorytetowych organizacji należeć będzie dążenie do pełnego równouprawnienia kobiet z mężczyznami, ze szczególnym uwzględnieniem zapewnienia kobietom polskim płac na równi z mężczyznami oraz równego dostępu do zawodów, zwłaszcza o szczególnym prestiżu społecznym. LKP miałaby z jednej strony nawiązywać do częściowego długoletniego dorobku LK, z drugiej zaś otwierałyby się dla niej nowe perspektywy aktywności, dotyczące większego niż dotychczas angażowania się w sprawy dotyczące różnych środowisk kobiecych ${ }^{18}$. Aktywność LKP w zakładach zatrudniajacych kobiety zapewnić jej miała bardziej ugruntowane wpływy wśród kobiet pracujących. Przewodnicząca ZG LK Jadwiga Biedrzycka ${ }^{19}$ podkreślała

${ }_{15}$ Nie może być demokracji bez kobiet, „Nasza Praca” 1981, nr 1, s. 16-17.

16 Zob. I. Ratman-Liwerska, Stowarzyszenie jako czynnik społeczno-wychowawczej aktywizacji kobiet (na przyktadzie badań na Białostocczyźnie), Białystok 1984, s. 96.

17 Liga wszystkich Polek, „Nasza Praca” 1981, nr 1, s. 18.

18 Zaangażowanie polityczne członkiń LKP dotyczyć miało włączenia się ich we współorganizację wyborów do sejmu i rad narodowych oraz „wystawiania” kandydatek do tych reprezentacji. Zob. M. Dajnowicz, „Zwierciadto”- platforma polityczna Ligi Kobiet w okresie PRL (1957-1961, 1982-1989), „Rocznik Historii Prasy Polskiej” 2017, nr 3, s. 82-87; eadem, Postanki Ligi Kobiet Polskich i wybory parlamentarne 1989 roku (prezentacja $w$ świetle „Zwierciadta”), w: Polityka i politycy w prasie XX $i$ XXI wieku. Polityka w prasie kobiecej, red. M. Dajnowicz, A. Miodowski, Białystok 2019, s. 205-215; A. Drozdowska, Liderki Ligi Kobiet wobec wyborów w latach 80. (W świetle „Naszej Pracy”), „Czasopismo Naukowe Instytutu Studiów Kobiecych” 2020, nr 1 (8), s. 198-205.

19 Jadwiga Biedrzycka - od 1982 r. do 1989 r. przewodnicząca ZG LKP. W 1985 r. wybrana na posła do Sejmu PRL IX kadencji. Pełniła funkcje wicemarszałka sejmu i zastępcy przewodniczącego Klubu Poselskiego PZPR. 
w przemówieniu podczas zjazdu dość ogólnikowo, że w programie organizacji priorytetowo traktowane będa sprawy kobiet dotyczące utrzymania ich godnej pozycji w społeczeństwie, równych praw kobiet i mężczyzn w rodzinie, życiu zawodowym i publicznym. Uważała, że organizacja powinna działać bardziej zdecydowanie niż w przeszłości, żądać jednocześnie od władz rządowych spełnienia wysuwanych przez nią konkretnych postulatów, odnoszących się zwłaszcza do polepszenia życia codziennego kobiet. Do osiagnięcia tych celów niezbędne miały być aktywność kobiet $\mathrm{w}$ różnorodnych działaniach $\mathrm{w}$ życiu zawodowym i publicznym oraz wprowadzenie w państwie polskim korzystnych dla kobiet zmian, m.in. poprzez ustawodawstwo dotyczące stricte kobiet $^{20}$.

VIII NZ LK zakończył się podjęciem uchwały o zmianie nazwy organizacji na Ligę Kobiet Polskich ${ }^{21}$. Najważniejszym polem działalności przyszłej organizacji miałoby być budowanie jej wpływów wśród kobiet pracujących zawodowo. Przewodnicząca Zarządu Wojewódzkiego (ZW) LKP w Łodzi Janina Suska-Janakowska ${ }^{22}$ już w czasie zjazdu zainicjować miała dyskusję wewnątrz wojewódzkich struktur organizacji, za priorytetowe uznając organizowanie kół Ligi w łódzkich zakładach pracy zatrudniajacych kobiety oraz poprzez działania liderek Ligi rozpoznanie codziennych i różnorodnych problemów kobiet z Łodzi i terenu województwa łódzkiego. Zapowiedziała także pomoc ze strony funkcjonujących przy Lidze KGD w rozwiązywaniu tych problemów ${ }^{23}$.

Niejako oddzielnie, na przełomie 1981 i 1982 r., skupiano się w kierunkach działalności ZW LKP w Łodzi na rozwiązywaniu bieżących problemów, jakimi zajmowano się $\mathrm{w}$ poszczególnych kołach organizacji z terenu województwa łódzkiego. W materiałach sprawozdawczych z działalności łódzkiej LKP podnoszono m.in. wciąż aktualne potrzeby powoływania w mieście i w terenie poradni przeciwalkoholowych i doradztwa prawnego oraz punktów pomocy społecznej ${ }^{24}$. Z inicjatywy Biura Politycznego KC PZPR odbyło się w lutym 1982 r. spotkanie z kierownictwem ZW LKP w Łodzi. Służyć miało ono wyznaczeniu kierunków codziennej współpracy między partią a organizacja, zwłaszcza w zakresie udzielenia przez partię wsparcia Lidze w umacnianiu

${ }^{20}$ Chcemy reprezentować interesy kobiet polskich, „Nasza Praca” 1982, nr 1, s. 28.

${ }^{21}$ Uchwała programowa VIII Nadzwyczajnego Zjazdu Krajowego Ligi Kobiet, Warszawa, 28 listopada 1981 r., „Nasza Praca” 1982, nr 1, s. 45-51; Rozporządzenie Rady Ministrów z dnia 2 grudnia 1982 r. w sprawie zmiany nazwy stowarzyszenia wyższej użyteczności „Liga Kobiet” na „Liga Kobiet Polskich” oraz nadania statutu temu stowarzyszeniu, Dz.U. 1982, nr 38, poz. 254.

22 Janina Suska-Janakowska - przewodnicząca ZW LK, następnie LKP w Łodzi w latach 1958-1989.

${ }^{23}$ Archiwum Ligi Kobiet Polskich w Łodzi (dalej: ALKPŁ), Zarząd Łódzki Ligi Kobiet, Informacja na temat przebiegu kampanii sprawozdawczo-wyborczej w Lidze Kobiet Polskich w województwie łódzkim, Łódź, dn. 23 XI 1982 r., s. 1-2.

${ }^{24}$ Ibidem, Zarząd Dzielnicowy LKP Łódź Bałuty, Informacja o czynach na rzecz osób niepełnosprawnych i inwalidów (1982 r.), s. 1. 
jej pozycji w zakładach pracy. Zakładano, że organizacja podejmie działania, które częściowo zastapiłyby zadania stawiane wcześniej związkom zawodowym. Za priorytetowe uznano również zaangażowanie łódzkiej Ligi w organizację kursów zawodowych kierowanych do łódzkich kobiet ${ }^{25}$.

Praca zawodowa, zwłaszcza w warunkach narastajacego kryzysu ekonomiczno-politycznego i związanego z tym niezadowolenia społecznego, miała być stawiana na pierwszym planie w życiu kobiety, stanowić kluczowa wartość związaną z interesem zakładu pracy, ważniejszym niekiedy od interesu jednostki, czyli w niniejszym przypadku pracującej kobiety ${ }^{26}$. Praca, w przypadku kobiet łódzkich głównie w zakładach włókienniczych, winna łączyć kobiety pracujące $\mathrm{w}$ ich funkcjonowaniu w społeczeństwie, zapewniając jednocześnie środki ekonomiczne niezbędne do życia codziennego kobiet i ich rodzin. Praca zawodowa stwarzać miała dla samych kobiet także możliwości rozwoju organizacyjnego i społecznego oraz karier zawodowych, stawać się ich wkładem w „budowanie i utrzymanie Polski socjalistycznej”27.

W dokształcenie zawodowe w postaci organizowanych kursów dla łodzianek zaangażowane były głównie KGD, w ramach których odbywały i cieszyły się popularnością wśród mieszkanek Łodzi kursy m.in. kroju i szycia, haftu, dziewiarstwa oraz tkactwa, jak również szkolenia przygotowujące do zawodu intendentek oraz kucharek. W zakresie prac szkoleniowych KGD promowała Liga wypracowanie wśród kobiet łódzkich gospodarności i oszczędności w życiu codziennym. Upowszechniano i popularyzowano, m.in. na łamach „Dziennika Łódzkiego", prace chałupnicze, które cieszyć się miały zainteresowaniem wśród kobiet niepracujących. Pisano także w tym periodyku na temat organizowanych przez KGD na terenie miasta kursów kroju i szycia, kierowanych do gospodyń domowych ${ }^{28}$. Kryzys ekonomiczny w kraju w pewnym zakresie wymuszał niejako na kobietach wypracowanie i wdrażanie w funkcjonowaniu codziennym zasad planowania, oszczędności, pomysłowości i operatywności. Uczono tych zasad podczas różnorodnych szkoleń organizowanych właśnie w KGD ${ }^{29}$.

W łódzkiej prasie lokalnej głos zabrała sekretarz struktur wojewódzkich LKP w Łodzi Elżbieta Bobrowska, informujacc czytelników o ciężkim położeniu kobiet w czasie trwajacego kryzysu społeczno-gospodarczego, w jakim znalazło się państwo polskie po $1982 \mathrm{r}$. Na barkach LKP spoczywać miała więc pomoc łódzkim kobietom, zwłaszcza pracującym, w „udźwignięciu ciężaru

${ }^{25}$ Ibidem, Spotkanie w Komitecie Łódzkim PZPR. Pomóc kobietom. Pomóc rodzinie, „Dziennik Łódzki”, 10 II 1982 (wycinek prasowy).

${ }^{26}$ K. Andrejuk, Awans społeczny kobiet $w$ czasach PRL. Dynamika struktury i sprawczości, „Przegląd Socjologiczny” 2016, nr 3, s. 170.

${ }_{27}$ M. Madejska, Aleja Wtókniarek, Wołowiec 2018, s. 179-180 i n.

${ }_{28}$ ALKPŁ, Gospodarność od strony kuchni, „Dziennik Łódzki”, 7 IV 1982 (wycinek prasowy).

${ }^{29}$ K. Stańczak-Wiślicz, „Jak zwiazać koniec z końcem”. Jedzenie i konsumpcja $w$ Polsce $w$ latach osiemdziesiatych $X X w . w$ dyskursie eksperckim $i$ kobiecych narracjach osobistych, „Rocznik Antropologii Historii” R. IV, 2014, s. 139-155. 
dnia codziennego”. Sekretarz podkreślała, że „kryzys polityczno-społeczny i gospodarczy w swych skutkach najdotkliwiej uderzał w żony i matki, które nie moga, z powodów ekonomicznych, pozwolić sobie na rezygnację z pracy zawodowej”. W związku z tym Liga zaangażować się miała w organizację licznych szkoleń i kursów dokształcających, z zakresu nie tylko prowadzenia oszczędnego gospodarstwa domowego, ale i edukacji ekonomicznej dotyczacej planowania budżetów rodzinnych i racjonalnego gospodarowania nimi, co winno dać efekt pozytywny w „radzeniu sobie” z uciążliwościami kryzysu ekonomicznego dotykającego mieszkańców regionu łódzkiego i kraju ${ }^{30}$. Powszechne, wręcz codzienne niedobory żywności, występujące w latach osiemdziesiątych, często podnoszono w dyskursie publicznym. To na barkach kobiet spoczywał obowiązek zapobiegania uciążliwościom tych niedoborów, których doświadczano na co dzień. LKP poprzez organizację poradnictwa, m.in. w funkcjonujących przy niej KGD, także przez publikacje w „Zwierciadle” czy „Naszej Pracy” na temat oszczędności, zasad gospodarności, wyuczonej operatywności w pokonywaniu trudów związanych z kryzysem ekonomicznym, w tym ze skutkami braku podstawowych produktów żywnościowych, miała być organizacją wspierająca polskie kobiety w dobie narastającego kryzysu w latach osiemdziesiątych ${ }^{31}$.

Około 1983 r. nastapiła pewnego rodzaju poprawa nastrojów społecznych wśród społeczeństwa polskiego, w tym kobiet, powodowana przejściowym wzrostem gospodarczym związanym z wydłużeniem czasu pracy, zmiana struktury eksportu, zwiększeniem produkcji ${ }^{32}$. W ramach działalności KGD zorganizowano w 1983 r. ponad 170 kursów oraz 250 pokazów dla kobiet z obszaru działalności ZW łódzkiej LKP. Ogromną popularnością cieszyć się miały również powoływane przy LKP w Łodzi poradnie społeczno-prawne, gdzie w sprawach głównie rozwodowych i alimentacyjnych udzielono w 1983 r. blisko 550 porad. W funkcjonujących placówkach dzielnicowych LKP wskazywano wciąż jako najistotniejsze prowadzenie działalności wśród kobiet w zakładach pracy oraz - choć w mniejszym stopniu - w ich miejscu zamieszkania. Jak podawano w materiałach sprawozdawczych, liczba kół LKP miała wzrosnąć w związku z ,ponownym wejściem” organizacji do zakładów pracy i w $1982 \mathrm{r}$. na obszarze okręgu łódzkiego działalność prowadziło ponad 230 kół skupiajacych blisko 12300 członkiń, z czego w zakładach pracy zarejestrowano 55 kół i 2300 członkiń. W ciagu następnych dwóch lat ponownie miała wzrosnąć liczebność kobiet zrzeszonych w łódzkiej Lidze. Pod koniec marca $1984 \mathrm{r}$. organizacja liczyła 284 koła i 17 tys. członkiń, z czego w zakładach pracy

\footnotetext{
${ }^{30}$ ALKPŁ, Ewa Kafarska, Kobietom teraz najtrudniej, „Głos Robotniczy” 1982 (wycinek prasowy).

${ }^{31}$ Zob. np.: K. Olechnowicz, Oszczędzanie - temat wieczny i bolesny, „Zwierciadło” 1983, nr 38, s. 3-4; M. Szymusiak, Kombinatorka, „Zwierciadło” 1983, nr 45, s. 5.

32 A.L. Sowa, Historia polityczna Polski 1944-1991, Kraków 2011, s. 586.
} 
funkcjonować miało 140 kół, do których należało ponad 9500 kobiet. Nie zadowalało natomiast zainteresowanie kobiet zrzeszaniem się w kołach osiedlowych, powoływanych w ich miejscach zamieszkania, do których należały głównie kobiety niepracujące zawodowo ${ }^{33}$.

Rok 1984 to okres podsumowań pracy członkiń LKP, od lat zaangażowanych w działania społeczne na terenie m.in. zakładów pracy, w których były zatrudnione. Według wspomnień jednej z działaczek organizacji z obszaru działalności Łódź-Bałuty szeregowe członkinie chętnie pomagały innym kobietom pracującym w danym zakładzie. Jednak praca społeczna na początku lat osiemdziesiątych miała być słabsza i jednocześnie mniej owocna w porównaniu ze wcześniejszym okresem, zwłaszcza latami siedemdziesiątymi. Zmniejszające się zaangażowanie społeczne kobiet związanych Liga w latach osiemdziesiątych wiązało się z pewnego rodzaju odczuwalna, również $\mathrm{w}$ strukturach LKP, atmosferą pesymizmu, co wynikać miało także ze skutków dotkliwego i narastającego $\mathrm{z}$ biegiem lat kryzysu ekonomicznego w Polsce, odczuwalnego po $1981 \mathrm{r}$. również przez kobiety zatrudnione w fabrykach łódzkich. Członkinie LKP, według wspomnień, w większości reprezentujące starsze pokolenie łodzianek, podsumowywały dotychczasowe swoje działania, traktujacc w pewnym sensie początek lat osiemdziesiątych jako okres zamknięcia wcześniejszej, przed 1981 r., wieloobszarowej i bardzo aktywnej działalności organizacji. Praca Ligi po 1982 r. postrzegana była w opinii jednej z autorek wspomnień jako schyłkowa, bez konkretnych wytycznych dla dalszej działalności i bez jasnej wizji rozwoju, bardziej negatywnie niż we wcześniejszym okresie oceniana także przez część społeczeństwa polskiego, w tym przez kobiety nienależące do Ligi ${ }^{34}$.

O działalności LKP w miejscu zamieszkania kobiet informowano przez całe lata osiemdziesiąte. ZG LK w 1984 r. podją uchwałę w tej sprawie, wskazując na zasadność angażowania się członkiń Ligi w organizowanie, zwłaszcza na osiedlach miejskich, konkursów związanych z edukacją dotycząca podnoszenia estetyki otoczenia $\mathrm{w}$ miejscach zamieszkania czy włączania się kobiet $\mathrm{z}$ organizacji w inicjowanie imprez o charakterze kulturalnym, które miałyby integrować inne kobiety, także niezrzeszone w Lidze ${ }^{35}$. Zadaniami LKP były również: pewnego rodzaju uspokajanie nastrojów społecznych, budzenie wśród kobiet poczucia obowiązku i odpowiedzialności za wspólne sprawy odnoszące się do przeciwdziałania kryzysowi i włączanie się organizacji w rozwiązywanie problemów wspólnych dla wszystkich kobiet polskich, dotyczących także

${ }^{33}$ ALKPŁ, Liga Kobiet Polskich, Zarząd Łódzki, Informacja na temat działalności Ligi Kobiet Polskich w woj. łódzkim, s. 1-6.

${ }^{34}$ Ibidem, Gabriela Garwacka, Moje wspomnienia i opowiadania, Zarząd Dzielnicowy LKP Łódź Górna, 1985, s. 52-63.

${ }^{35}$ Uchwała Zarzadu Głównego Ligi Kobiet Polskich w sprawie dalszej społecznej aktywizacji kobiet w miejscu zamieszkania, Zarzad Gtówny Ligi Kobiet Polskich, Warszawa, grudzień 1984 r., „Nasza Praca” 1985, nr 3, s. 6-7. 
wciąż narastających od połowy lat osiemdziesiątych uciążliwości „dotkliwych ekonomicznie" w życiu codziennym ${ }^{36}$.

Od połowy lat osiemdziesiątych nasiliły się skutki kryzysu gospodarczego, a zauważalny ok. 1983 r. wzrost gospodarczy został zahamowany. Rosnące ceny towarów i inflacja wpływały niekorzystnie na nastroje społeczne. Z danych zebranych i opracowanych przez Ośrodek Badania Opinii Publicznej wynikało, że od połowy lat osiemdziesiątych „systematycznie malała grupa osób oceniających przeżyty rok jako dobry, a rosła liczba ocen definiowanych jako złych i bardzo złych" ${ }^{37}$. W tym czasie, także na łamach prasy kobiecej, pojawiały się informacje o bardzo ciężkich warunkach pracy kobiet łódzkich, zwłaszcza w sektorze włókiennictwa ${ }^{38}$. Na łamach periodyku kobiecego wywiadu udzieliła wówczas m.in. Barbara Sieradzka, wiceprzewodnicząca Rady do Spraw Kobiet przy Ogólnopolskim Porozumieniu Związków Zawodowych, pracujacca w Zakładach Przemysłu Bawełnianego im. S. Dubois „Polino” w Łodzi. W wywiadzie tym zwracała uwagę, że absencja chorobowa powodowana złymi warunkami pracy jest w tych zakładach wyższa o ok. $12 \%$ w porównaniu z zakładami z sektora pozawłókienniczego ${ }^{39}$. Przepisy o ochronie pracy kobiet wielokrotnie nowelizowano, m.in. rozszerzona została lista prac wzbronionych kobietom, obejmująca kilkaset pozycji, co miało wpłynać na lepsze ogólne warunki pracy ${ }^{40}$. W praktyce jednak wprowadzane przepisy nie były przestrzegane, co akceptowały w dużej mierze i same kobiety, kierując się głównie potrzebą utrzymania pracy. Na podjęcie ciężkiej pracy decydować się miały zwłaszcza kobiety samotne lub samodzielnie utrzymujące rodzinęę ${ }^{41}$

W'́ród pilnych zadań wytyczanych do realizacji na rok 1985 i następne lata ZG LKP wskazywać miał dalszą konieczność umacniania pracy kół i ich rozwój w zakładach pracy oraz na osiedlach, w których mieszkały kobiety i ich rodziny. LKP zwracała uwagę na konieczność pozyskiwania do organizacji kobiet z tzw. młodego pokolenia, ewentualnych przyszłych liderek i członkiń Ligi. Pojawiły się w jej programie kwestie dotyczace podnoszenia świadomości zdrowotnej kobiet polskich, co miałoby być realizowane we wspólnych działaniach Ligi oraz Resortu Zdrowia i Opieki Społecznej. Za niezwykle istotne uznawano także upowszechnianie wśród kobiet edukacji prawnej

${ }^{36}$ K. Stachowicz, Nie uchylajmy się od obowiazków, „Zwierciadło” 1985, nr 37, s. 2-3; D. Wójcik, Równość - rozwój - pokój - szansq dla kobiet, „Zwierciadło” 1985, nr 32, s. 6.

${ }^{37}$ A.L. Sowa, op. cit., s. 597.

${ }^{38}$ M. Madejska, op. cit., s. 242 i n.

${ }^{39}$ Przemyst lekki - praca ciężka, „Kobieta i Życie” 1987, nr 21, s. 4-5.

${ }^{40}$ Rozporządzenie Rady Ministrów z dnia 5 września 1984 r. zmieniające rozporządzenie w sprawie wykazu prac wzbronionych kobietom, Dz.U. 1984, nr 44, poz. 235.

${ }^{41}$ U. Sokołowska, „Role społeczne kobiet w świetle periodyku «Kobieta i Życie» na tle rzeczywistości Polskiej Rzeczpospolitej Ludowej w latach 1970-1989”, praca doktorska, mps, Białystok 2018, s. 256. 
i ekonomicznej, w tym drugim przypadku w zakresie wciąż ważnego w opinii Ligi zagadnienia prowadzenia przez kobiety oszczędnych budżetów rodzinnych ${ }^{42}$.

Na obszarze okręgu łódzkiego Liga liczyć miała w 1986 r. 332 koła zrzeszające ponad 23 tys. członkiń. Wciąż aktywnie działały placówki LKP w łódzkich zakładach pracy zatrudniających kobiety. Należy podkreślić, że w porównaniu z innymi obszarami Polski w województwie łódzkim (po katowickim) notowano w tym czasie największą liczbę kół LKP ${ }^{43}$. Funkcjonować również miały, cieszace się zainteresowaniem łodzianek, poradnie prawno-rodzinne, w których w 1986 r. udzielono 60 porad w zakresie problemów rodzinnych ${ }^{44}$. Dodać należy, że podając stan organizacyjny LKP w 1987 r., zawarto informację, że Liga w Polsce liczyła wówczas ponad 570 tys. członkiń skupionych w blisko 11500 kołach. Najwięcej zaś kół LKP z okręgu łódzkiego funkcjonowało w zakładach pracy zatrudniajacych kobiety ${ }^{45}$.

W październiku 1986 r. odbył się IX NZ LKP, podczas którego przyjęto program działania organizacji do $1990 \mathrm{r}$. W wytycznych programowych podkreślano konieczność większej aktywności niż dotychczas kół zakładowych, które m.in. „usuwać powinny bariery hamujace awans kobiet”. Zakładano ponadto rozwój poradnictwa dla kobiet, zwłaszcza rodzinno-prawnego. Za kwestię priorytetową uznawano dalszą działalność Ligi w zakładach pracy i zwiększanie liczby członkiń rekrutowanych pośród młodych kobiet. Harmonijną współpracę Polek zrzeszonych i niezrzeszonych w Lidze upowszechniać miały obchody Międzynarodowego Dnia Kobiet 8 marca, w 1987 r. ogłoszonego przez Ligę Kongresem Kobiet. W popularyzowaniu zaś zagadnień przyjętych w niniejszym programie na lata 1987-1990 zakładano dalszą współpracę organizacji, m.in. z prasa kobieca ${ }^{46}$.

Do ZW LKP w Łodzi przekazano uchwałę ZG LKP z 1988 r. w sprawie awansu zawodowego i społecznego kobiet polskich. Wskazano w niej na problem niedostatecznego awansu zawodowego kobiet i zaakcentowano konieczność włączenia się kół zakładowych Ligi w kwestie awansów kobiet oraz zrównania płacy ich i mężczyzn świadczacych pracę na takich samych stanowiskach zawodowych. W zamyśle Ligi koła zakładowe miały zastępować

${ }^{42}$ Kierunki działania Ligi Kobiet Polskich w 1985 r., Zarzqd główny Ligi Kobiet, Warszawa, styczeń 1985 r., „Nasza Praca” 1985, nr 3, s. 1-3.

${ }^{43}$ ALKP€, Sprawozdanie z działalności Zarządu Łódzkiego LKP w roku 1986, s. 2 i n.

${ }^{44}$ Ibidem, s. 8-11.

${ }^{45}$ Ibidem, Wydział Organizacyjny Zarządu Głównego Ligi Kobiet Polskich, Informacja o stanie organizacyjnym Ligi Kobiet Polskich, s. 1, 4. Należy dodać, że w tym czasie 11 zarządów dzielnicowych i miejskich podlegało ZW LKP w Łodzi.

${ }^{46}$ Archiwum Instytutu Pamięci Narodowej w Warszawie, BU 01728/52, Kierunki działania Ligi Kobiet Polskich w 1987 r. Projekt, Warszawa, styczeń 1987 r., k. 106-108; ibidem, Sprawozdanie z działalności Ligi Kobiet w latach 1979-1981, Warszawa, listopad 1981, k. 82; ibidem, Założenie przeglądu struktur organizacyjnych, atestacji stanowisk pracy oraz przeglądu kadrowego w Lidze Kobiet Polskich, [b.d.], k. 126. 
związki zawodowe, być reprezentacją kobiet pracujących, także tych, które nie były formalnymi członkiniami LKP ${ }^{47}$.

W 1989 r. nr 1 „Naszej Pracy” poświęcono analizie aktywności organizacji w miejscu zamieszkania kobiet, wskazując na błędy w tym zakresie popełnione przez Ligę. Miało to na celu pokazanie czytelniczkom, że aktualnie, w czasach przełomu politycznego, od końca lat osiemdziesiątych, LKP może i potrafi w skuteczny sposób prowadzić działalność wśród Polek na wielu płaszczyznach. „Nasza Praca” miała być pewnego rodzaju poradnikiem metodycznym, w którym zawierano wskazania dla dalszej działalności organizacji. Podano zainteresowanym, że w tym czasie w kraju działalność prowadziło ponad 1800 kół LKP w miejscu zamieszkania, skupiających 78 tys. członkiń. Podkreślano, że koła te, w odróżnieniu od kół zakładowych, zajmują się codziennymi i realnymi problemami kobiet, także niepracujących, oraz przede wszystkim problemami ich rodzin. Działania te miały wpływać pozytywnie na pogłębienie zaufania do organizacji, służyć integracji różnych kobiecych środowisk z poszczególnych osiedli miejskich ${ }^{48}$. W celu skuteczniejszej pracy organizacji przygotowano w 1989 r. wytyczne dla działalności Ligi w małych społecznościach lokalnych. Pracy LKP na osiedlach sprzyjać miałaby jej współpraca z samorządem mieszkańców w zakresie organizacji wspólnych inicjatyw służacych integracji młodzieży i rozwijaniu dalszej działalności Ligi w klubach osiedlowych ${ }^{49}$. Do najważniejszych zadań wskazywanych do realizacji w 1989 r. należało również kontynuowanie współpracy kół osiedlowych LKP z zakładowymi. Liga zapowiedziała włączenie się w kampanię wyborczą do Sejmu X kadencji, rekomendujac kandydatki z LKP na posłanki ${ }^{50}$. Ponadto podkreślano kontynuowanie wcześniejszych działań w poszczególnych kołach, m.in. na rzecz oświaty, aktywności poradniczej w zakresie profilaktyki zdrowotnej. Jednocześnie na łamach biuletynu „Nasza Praca” wciąż upowszechniano problematykę dotycząca prowadzenia przez kobiety nowoczesnego, a zarazem funkcjonalnego gospodarstwa domowego ${ }^{51}$. LKP przedstawiała także opinie odnoszące się do przyszłych kierunków rozwoju polityki socjalnej w PRL, m.in. wysokości zasiłków rodzinnych, rent inwalidzkich, emerytur ${ }^{52}$.

Na łamach „Naszej Pracy” opublikowano apel Prezydium ZW LKP z września 1989 r., w którym zostało wyrażone „głębokie zaniepokojenie kobiet, na barkach których spoczywa w głównej mierze gospodarka budżetami

\footnotetext{
${ }^{47}$ ALKP£, Uchwała Zarządu Głównego Ligi Kobiet Polskich z dnia 24 lutego 1988 r., s. 1-2.

${ }_{48}$ Szeroko otwarte drzwi dla kót w miejscu zamieszkania, „Nasza Praca” 1989, nr 1, s. 10.

${ }^{49}$ Uchwała Zarzqdu Gtównego w sprawie dalszego rozwoju i umacniania kót LKP w miejscu zamieszkania, „Nasza Praca” 1989, nr 1, s. 19 i n.

${ }^{50}$ M. Dajnowicz, Posłanki Ligi Kobiet Polskich i wybory parlamentarne..., s. 205-215.

${ }^{51}$ A. Zdybel, Wspótczesne gospodarstwa domowe $w$ Polsce $w$ świetle badań i prognoz, „Nasza Praca" 1989, nr 2, s. 8-12.

52 Opinie LKP. Polityka socjalna w PRL. Propozycje kierunków jej systemowych zmian. Synteza. Założenia, „Nasza Praca” 1989, nr 2, s. 13 i n.
} 
domowymi”. Przypominano o proteście kobiet pracujących w Łódzkich Zakładach Przemysłu Gumowego „Stomil”, co świadczyć miało o kryzysie zaufania do ówczesnej polityki rządu. Pisano, że „szczególnie dotkliwe są odczuwalne codzienne, wysokie podwyżki cen na podstawowe artykuły spożywcze, niezbędne w żywieniu każdej rodziny. Dodatki osłonowe, mające zrekompensować skutki urynkowienia gospodarki, nie pokrywały w żadnym stopniu wielokrotnych podwyżek cen. W związku z tym prezydium ZW łódzkiej LKP uważało, iż konieczne jest podjęcie przez rząd natychmiastowych działań, zmierzających do zahamowania inflacji”" ${ }^{33}$. Zwracano się także do przedstawicieli związków zawodowych, w tym do Niezależnego Samorządnego Związku Zawodowego „Solidarność” o poparcie postulatów wysuwanych przez łódzka LKP $\mathrm{w}$ zakresie podwyższenia płac kobietom, ze względu m.in. na rosnące ceny produktów ${ }^{54}$. Kobiety z łódzkiej LKP zabrały również głos w dyskusji odnośnie do projektu ustawy o ochronie dziecka poczętego, której treść oceniały bardzo krytycznie, jako ingerująca dotkliwie w prawa kobiet ${ }^{55}$. W maju 1989 r. kobiety z koła LKP z dzielnicy Łódź-Górna wypowiedziały się także na temat oceny projektu tejże ustawy, wskazując, że do dyskusji nad treścia ustawy powinno się przede wszystkim włączyć same kobiety i to z różnych środowisk. Poza tym za niezwykle istotne uznawano, w celu podniesienia świadomości kobiet przy planowaniu rodziny, podjęcie przez rząd działań w zakresie „upowszechniania oświaty sanitarnej oraz w zakresie szeroko rozumianej antykoncepcji” ${ }^{\circ 6}$.

Już od połowy 1988 r. nieskuteczna polityka gospodarcza państwa budziła coraz większe niezadowolenie społeczne, które objawiało się m.in. protestami ulicznymi i strajkami w zakładach pracy ${ }^{57}$. W poszczególnych kołach LKP od końca 1988 r. zaczęto podejmować ożywioną dyskusję nad przyszłością organizacji. Z jednej strony zapowiadano kontynuowanie wcześniejszych działań zmierzających do „łagodzenia” skutków kryzysu związanego z przemianami ustrojowymi i gospodarczymi końca lat osiemdziesiątych, z drugiej zaś zastanawiano się nad nowymi możliwościami w zakresie kierunków przyszłej działalności Ligi ${ }^{58}$. W 1989 r. ZG LKP podjął uchwałę dotyczącą prowadzenia

${ }^{53}$ Prezydium Zarządu Łódzkiego Ligi Kobiet Polskich, Głos Łódzkich Kobiet w sprawie aktualnej sytuacji rodzin, Łódź 9 września 1989, „Nasza Praca” 1989, nr 11-12, s. 2.

54 Ibidem.

${ }^{55}$ LKP prowadziła szeroką kampanię na ten temat w prasie, m.in. na łamach „Zwierciadła”. Stanowisko Ligi Kobiet Polskich w sprawie dopuszczalności przerywania ciaży, „Zwierciadło" 1989 , nr 18, s. 4-5.

56 ALKPŁ, Zarząd dzielnicowy Łódź Górna, Stanowisko kobiet wobec ustawy „O ochronie dziecka poczętego", maj 1989 r., s. 1.

${ }^{57}$ A.L. Sowa, op. cit., s. 598.

${ }^{58} \mathrm{~W}$ świetle przeprowadzonych przez Magdalenę Grabowską badań socjologicznych, w tym opartych na wywiadach z działaczkami Ligi, również dla kobiet z Łodzi, lata osiemdziesiąte postrzegane były przez członkinie organizacji jako czas kryzysu i braku podstawowych produktów w sklepach. Natomiast w świetle jednej z wypowiedzi kobiety z Ligi 
przez nią działalności gospodarczej ${ }^{59}$. W celu wzmocnienia pozycji organizacji oraz jej dostosowania do zmian polityczno-gospodarczych pojawiły się w jej wewnętrznych strukturach koncepcje odnoszące się do przekształcenia LKP w spółkę. Realizacja tych planów miałaby zapewnić środki finansowe potrzebne do funkcjonowania i rozwoju organizacji w nowej rzeczywistości po 1989 r. ${ }^{60}$ Według oficjalnych statystyk LKP w 1989 r. liczyła ponad 590 tys. członkiń, z czego $20 \%$ to kobiety, które nie ukończyły 30 lat oraz $17 \%$ to kobiety starsze, tj. emerytki niepracujące już zawodowo ${ }^{61}$.

Podsumowując, należy stwierdzić, że LKP, organizacja funkcjonująca $\mathrm{w}$ ostatnim dziesięcioleciu PRL, miała być ruchem wspierajacym działania rządu i partii komunistycznej w zakresie budowy zaufania wśród ogółu kobiet, w okresie narastającego po 1982 r. kryzysu ekonomicznego, społecznego, politycznego. Szczególnym polem działalności i co za tym idzie - wpływów organizacji winny być zakłady pracy zatrudniające kobiety. W pewnym stopniu LKP miała zastapić również związki zawodowe, starając się w ten sposób reprezentować interesy kobiet pracujących oraz umacniać pozycję w tych środowiskach. Innymi zadaniami liderek organizacji były budowanie i utrzymanie wpływów w społecznościach lokalnych, w dzielnicach i na osiedlach miejskich. Skuteczność Ligi w okręgu łódzkim miała iść $\mathrm{w}$ parze ze zwiększającą się liczebnością członkiń. W celu jej uwiarygodnienia i budowania popularności w różnych środowiskach kobiecych oraz zaufania do LKP wśród kobiet łódzkich organizowano różnorodne kursy i szkolenia w ramach działalności KGD, którego cel stanowiło wyuczenie łodzianek przede wszystkim zasad gospodarności, oszczędności, zarządzania domem i jego budżetem oraz odpowiedzialności za ekonomiczne prowadzenie gospodarstw domowych w czasach narastającego w latach osiemdziesiątych kryzysu ekonomicznego i politycznego.

Skuteczność organizacji mogła objawiać się w pojedynczych inicjatywach Ligi, pracy eksperckiej (np. zaangażowanie liderek w opiniowanie przepisów prawnych), także operatywności w „załatwianiu” spraw dotyczących kobiet zgłaszających się po pomoc. Kierunki działalności łódzkiej LKP zależały w znaczącej mierze od zadań wyznaczanych przez ZG LKP i konkretnych wytycznych nakreślanych w KC PZPR. Kobiety miały być również bardzo

„transformacja na tym polegała, że wszystko popadało w ruinę i zaczęto zwalniać ludzi”. Cyt. za: M. Grabowska, op. cit., s. 152.

${ }^{59}$ Uchwała Zarzadu Gtównego Ligi Kobiet Polskich w sprawie prowadzenia dziatalności gospodarczej w LKP, Warszawa, 27 września 1989 r., „Nasza Praca” 1989, nr 11-12, s. 7.

${ }^{60}$ K. Stachowicz, Miejsce Ligi, „Zwierciadło” 1989, nr 8, s. 7.

${ }^{61}$ Jaka organizacja kobieca i jaki jej program?, „Nasza Praca” 1989, nr 11-12, s. 8. Pod koniec lat siedemdziesiątych PZPR liczyła ponad 3 mln członków (tj. 12\% dorosłej populacji). W grudniu 1981 r. zrzeszała 2693357 członków i kandydatów. Pod koniec 1988 r. do partii należało 2132060 Polaków, zaś w styczniu 1990 r. członków było ok. 2 mln. M. Żukowski, Wybrane aspekty dotyczace PZPR w latach 1948-1990 (liczebność, sktad społeczny, dewizowe sktadki członkowskie i nomenklatura kadr), „Komunizm: System Ludzie - Dokumentacja” 2013, t. II, s. 125 i n. 
ważnym wsparciem w realizacji polityki partii i rządu. Realizacja programu upowszechnianego przez KGD, funkcjonujacego z ramienia LKP, dotyczacego wyuczenia kobiet oszczędności, gospodarności i następnie przedstawienia Polek jako kobiet oszczędnych, gospodarnych, jednocześnie nowoczesnych oraz cierpliwie znoszących uciążliwości kryzysu gospodarczego i politycznego, pozostawało w sprzeczności z rzeczywistościa, w której to kobiety, w życiu codziennym, boleśnie doświadczały skutków kryzysu, uwidocznionego chociażby w powszechnym niedoborze żywności.

Po 1982 r. LKP miała za zadanie, w związku z kryzysem ekonomicznym i politycznym, propagowanie wśród kobiet zasad oszczędności, gospodarności i pomysłowości w pokonywaniu trudów dnia codziennego, upowszechnianie w przestrzeni publicznej wizerunku kobiet polskich gospodarnych, nowoczesnych, zaangażowanych $\mathrm{w}$ pracę zawodową i w pewnym zakresie społeczna, oddanych rodzinie oraz wspierających państwo w pokonywaniu kryzysu, którego skutki odczuwały kobiety codziennie. LKP winna również zapobiegać w pewnym zakresie, poprzez realizację różnych zadań, narastającej w społeczeństwie w latach osiemdziesiątych atmosferze bezradności i niepokoju, związanej z pogłębiającym się kryzysem. Czyniła próby włączania się w ogólnospołeczna debatę na temat spraw i praw dotyczących kobiet, podejmowała się pomocy kobietom poprzez szerokie poradnictwo czy licznie organizowane szkolenia i kursy przygotowujace je do konkretnej aktywności zawodowej.

Za słabości LKP, uwidaczniane wciąż w niedostatecznej, w opinii organizacji, liczebności członkiń oraz w działalności, która nie przynosiła niekiedy oczekiwanych wymiernych efektów w postaci realnej pomocy dla kobiet, $\mathrm{w}$ tym dla niezrzeszonych w Lidze, odpowiadać miały organizacja i jej liderki. Problematyka oceny krytycznej polityki państwa, kryzysu i związanej z nim niewydolności państwa generalnie nie występowała w oficjalnych przekazach sprawozdawczych LKP. Zakres działań Ligi dyktowany był „odgórnymi” wytycznymi ze strony państwa i partii oraz - choć w mniejszym stopniu warunkowany aktywnością lokalnych liderek - niekiedy i oddolnymi potrzebami kobiet zgłaszających się do Ligi. To użyteczność organizacji uwidoczniona w realizacji pomocy dla kobiet decydować mogła o jej tzw. sprawczości. Sądzić jednak należy, że same działaczki nie do końca wierzyły w możliwości rozwoju własnej niezależnej i indywidualnej działalności oraz skuteczności, kiedy to zwłaszcza od połowy lat osiemdziesiątych narastała w społeczeństwie polskim krytyka szeroko rozumianego systemu (w tym i LKP zwiazanej z tym systemem), widoczna m.in. w strajkach i ogólnej atmosferze niezadowolenia społecznego. Próby pewnego rodzaju reformy organizacji, w związku z narastającym szeroko rozumianym kryzysem, można było dostrzec ok. 1988 r., kiedy to liderki formułowały m.in. oficjalne apele do władz o większe zainteresowanie sprawami kobiet i ich problemami, włączały się w dyskusje eksperckie nad kształtem ustaw ich dotyczących, mówiły o podejmowaniu ewentualnych wspólnych z Solidarnością działań na rzecz kobiet. 
Były to próby dostosowania się LKP do zmieniającej się rzeczywistości i co za tym idzie - przemian politycznych, społecznych, gospodarczych pod koniec lat osiemdziesiątych.

\section{Streszczenie}

Artykuł dotyczy zagadnienia głównych kierunków działalności organizacji o nazwie Liga Kobiet Polskich w latach 1982-1989 w okręgu łódzkim. Organizacja funkcjonowała w przestrzeni społeczno-politycznej Polski Ludowej od 1945 r. (początkowo 1949 r. pod nazwą Społeczno-Obywatelska Liga Kobiet, następnie do 1981 r. jako Liga Kobiet). Na lata osiemdziesiąte, okres narastajacego w Polsce kryzysu ekonomicznego i politycznego, przypadł schyłek jej zasięgu oddziaływania w środowiskach kobiet łódzkich, powodowany m.in. utratą zaufania kobiet niezrzeszonych w Lidze do organizacji, która utożsamiana była w ogólnym odbiorze społecznym z upadającym w tym czasie systemem komunistycznym. W programie LKP za priorytetowe uznawała działania organizacji w zakresie dążeń do pełnego równouprawnienia kobiet z mężczyznami, ze szczególnym uwzględnieniem zapewnienia kobietom polskim płac na równi z mężczyznami oraz równego dostępu do zawodów, zwłaszcza o szczególnym prestiżu społecznym. Łódzka LKP zaangażowała się ponadto w tym czasie w organizowanie kół Ligi w zakładach pracy zatrudniajacych kobiety. W dokształcenie zawodowe w postaci organizowanych kursów dla łodzianek zaangażowane były głównie Koła Gospodarstwa Domowego funkcjonujące wewnątrz struktur Ligi. Poważną popularnością wśród kobiet łódzkich, także niezrzeszonych w organizacji cieszyć się miały również powoływane przy LKP w Łodzi poradnie społeczno-prawne, gdzie w sprawach głównie rozwodowych i alimentacyjnych udzielano licznych porad. Zakres działań LKP dyktowany był jednak głównie „odgórnymi” wytycznymi ze strony państwa i partii.

\section{The Polish Women's League in the District of Łódź in 1982-1989. Main Directions of Its Activity in the Light of the Organisation's Reporting Materials}

The article presents the main directions of the activity of the organisation called Polish Women's League in 1982-1989 in the district of Lódź. The organisation functioned in the social and political reality of the Polish People's Republic since 1945 (initially, until 1949, under the name of the Social and Civic League of Women, then, until 1981, as the League of Women). The 1980s, a period of growing economic and political crisis in Poland, saw the decline in the League's reach within the community of Łódź women, caused, among other things, by the loss of trust towards the organisation of those women who were not associated with the League, which was generally perceived as an embodiment of the communist system in decline at that time. In its programme, the League prioritised the organisation's activities aimed to achieve full equality between women and men, with particular emphasis on ensuring Polish women wages on equal footing with men and equal access to professions, especially those of high social prestige. The League in Łódź was also involved in organising its circles in workplaces employing women. The vocational training in the form of organised courses for women from Łódź was mainly provided by the Household Circles operating within the League's structures. The social and legal counselling centres established at the League in Łódź, which provided advice on divorce and alimony cases, also enjoyed considerable popularity among Łódź women, including those not associated with the organisation. However, the scope of the League's activities was dictated mainly by 'top-down' guidelines from the state and the Polish United Workers' Party. 


\section{Bibliografia}

Andrejuk K., Awans społeczny kobiet w czasach PRL. Dynamika struktury i sprawczości, „Przegląd Socjologiczny” 2016, nr 3, s. 157-179.

Dajnowicz M., Gtówne kierunki działalności Ligi Kobiet w Polsce Ludowej do 1975 roku (ze szczególnym uwzględnieniem województwa białostockiego), „Prace Historyczne” 2018, nr 145 (3), s. 579-601.

Dajnowicz M., Liga Kobiet w okręgu łódzkim w latach 1945-1981. Główne obszary działalności, „Dzieje Najnowsze” 2019, nr 4, s. 75-90.

Dajnowicz M., Liga Kobiet $w$ terenie. Kierunki działalności organizacji na przykładzie struktur białostockich w latach 1966-1981, „Niepodległość i Pamięć” 2018, t. XXV, nr 2, s. 161-182.

Dajnowicz M., Postanki Ligi Kobiet Polskich i wybory parlamentarne 1989 roku (prezentacja $w$ świetle „Zwierciadta”), w: Polityka i politycy w prasie XX $i$ XXI wieku. Polityka w prasie kobiecej, red. M. Dajnowicz, A. Miodowski, Białystok 2019, s. 205-215.

Dajnowicz M., „Zwierciadto” - platforma polityczna Ligi Kobiet w okresie PRL (1957-1961, 1982-1989), „Rocznik Historii Prasy Polskiej” 2017, t. XX, nr 3, s. 67-90.

Drozdowska A., Liderki Ligi Kobiet wobec wyborów w latach 80. (W świetle „Naszej Pracy”), „Czasopismo Naukowe Instytutu Studiów Kobiecych” 2020, nr 1 (8), s. 198-205.

Drozdowska A., Liga Kobiet $w$ województwie białostockim - stan badań i postulaty badawcze, „Czasopismo Naukowe Instytutu Studiów Kobiecych” 2018, nr 2 (5), s. 112-127.

Fidelis M., Kobiety, komunizm i industrializacja $w$ powojennej Polsce, Warszawa 2015.

Grabowska M., Zerwana genealogia. Działalność społeczna i polityczna kobiet po 1945 roku a wspótczesny polski ruch kobiecy, Warszawa 2018.

Jarosz D., Idee, programy i realia: funkcje Ligi Kobiet $w$ porzqdku instytucjonalnym Polski Ludowej (1945-1957), w: Działaczki społeczne, feministki, obywatelki... Samoorganizowanie sie kobiet na ziemiach polskich po 1918 roku (na tle porównawczym), t. II, red. A. Janiak-Jasińska, K. Sierakowska, A. Szwarc, Warszawa 2009, s. 307-330.

Jarska N., Kobiety $z$ marmuru. Robotnice $w$ Polsce $w$ latach 1945-1960, Warszawa 2015.

Kenney P., Pojęcie „matki-Polki” w języku opozycji i władzy, w: Komunizm. Ideologia, system, ludzie, red. T. Szarota, Warszawa 2001, s. 344-351.

Madejska M., Aleja Włókniarek, Wołowiec 2018.

Marcinkiewicz-Kaczmarczyk A., Rola kobiety $w$ Polsce Ludowej w świetle treści propagandowych rozpowszechnianych przez Lige Kobiet w latach 1946-1956, „Dzieje Najnowsze” 2018, nr 2, s. 149-179.

Miodowski A., Local conditions for the activities of the League of Women structures in the Lower Silesia during the Stalinist period, „Społeczeństwo i Polityka” 2018, nr 4 (57), s. 137-155.

Miodowski A., Udziat dolnoślaskiej Ligi Kobiet w kampaniach propagandowych na rzecz aktywizacji zawodowej kobiet ze środowisk patologicznych $i$ aspołecznych (1949-1955), „Niepodległość i Pamięć” 2019, t. XXVI, nr 1, s. 279-302.

Ratman-Liwerska I., Stowarzyszenie jako czynnik społeczno-wychowawczej aktywizacji kobiet (na przykładzie badań na Białostocczyźnie), Białystok 1984.

Sokołowska U., „Role społeczne kobiet w świetle periodyku «Kobieta i Życie» na tle rzeczywistości Polskiej Rzeczpospolitej Ludowej w latach 1970-1989”, mps, praca doktorska, Białystok 2018.

Sowa A.L., Historia polityczna Polski 1944-1991, Kraków 2011.

Stańczak-Wiślicz K., „Jak zwiazać koniec z końcem”. Jedzenie i konsumpcja w Polsce w latach osiemdziesiatych XX w. w dyskursie eksperckim i kobiecych narracjach osobistych, „Rocznik Antropologii Historii” R. IV, 2014, s. 139-155.

Żukowski M., Wybrane aspekty dotyczqce PZPR w latach 1948-1990 (liczebność, skład społeczny, dewizowe sktadki członkowskie i nomenklatura kadr), „Komunizm: System Ludzie - Dokumentacja” 2013, t. II, s. 123-140. 
Małgorzata Dajnowicz - prof. dr hab., kierownik Katedry Historii Kultury oraz Pracowni Historii Kobiet na Wydziale Historii i Stosunków Międzynarodowych Uniwersytetu w Białymstoku. Zainteresowania naukowe: historia elit politycznych XIX i XX w., historia kobiet polskich. W ramach projektu Ministerstwa Nauki i Szkolnictwa Wyższego powołała Ośrodek Badań Historii Kobiet. Od 2018 r. Podlaska Wojewódzka Konserwator Zabytków. Więcej na stronie prywatnej: www.dajnowicz.pl. E-mail: malgorzatadajnowicz@gmail.com.

Małgorzata Dajnowicz - Prof. Dr Hab., head of the Department of History of Culture and the Women's History Section at the Faculty of History and International Relations at the University of Białystok. Research interests: history of the 19th- and 20th-century political elites, history of Polish women. As part of the project of the Ministry of Science and Higher Education, she established the Women's History Research Centre. Since 2018, she is the Podlasie Voivodeship Conservator of Monuments. More on her private website: www.dajnowicz.pl. E-mail: malgorzatadajnowicz@gmail.com. 